\title{
miR-34a and miR-15a/16 are co-regulated in non- small cell lung cancer and control cell cycle progression in a synergistic and Rb-dependent manner
}

Nora Bandi and Erik Vassella*

\begin{abstract}
Background: microRNAs (miRNAs) are small non-coding RNAs that are frequently involved in carcinogenesis. Although many miRNAs form part of integrated networks, little information is available how they interact with each other to control cellular processes. miR-34a and miR-15a/16 are functionally related; they share common targets and control similar processes including $G_{1}-S$ cell cycle progression and apoptosis. The aim of this study was to investigate the combined action of miR-34a and miR-15a/16 in non-small cell lung cancer (NSCLC) cells.

Methods: NSCLC cells were transfected with miR-34a and miR-15a/16 mimics and analysed for cell cycle arrest and apoptosis by flow cytometry. Expression of retinoblastoma and cyclin E1 was manipulated to investigate the role of these proteins in miRNA-induced cell cycle arrest. Expression of miRNA targets was assessed by real-time PCR. To investigate if both miRNAs are co-regulated in NSCLC cells, tumour tissue and matched normal lung tissue from 23 patients were collected by laser capture microdissection and compared for the expression of these miRNAs by realtime PCR.
\end{abstract}

Results: In the present study, we demonstrate that miR-34a and miR-15a/16 act synergistically to induce cell cycle arrest in a Rb-dependent manner. In contrast, no synergistic effect of these miRNAs was observed for apoptosis. The synergistic action on cell cycle arrest was not due to a more efficient down-regulation of targets common to both miRNAs. However, the synergistic effect was abrogated in cells in which cyclin E1, a target unique to miR15a/16, was silenced by RNA interference. Thus, the synergistic effect was due to the fact that in concerted action both miRNAs are able to down-regulate more targets involved in cell cycle control than each miRNA alone. Both miRNAs were significantly co-regulated in adenocarcinomas of the lung suggesting a functional link between these miRNAs.

Conclusions: In concerted action miRNAs are able to potentiate their impact on $\mathrm{G}_{1}-\mathrm{S}$ progression. Thus the combination of miRNAs of the same network rather than individual miRNAs should be considered for assessing a biological response. Since miR-34a and miR-15a/16 are frequently down-regulated in the same tumour tissue, administrating a combination of both miRNAs may also potentiate their therapeutic impact.

Keywords: cell cycle control, microRNA, non-small cell lung cancer, retinoblastoma, synergism

\footnotetext{
* Correspondence: erik.vassella@pathology.unibe.ch

Institute of Pathology, University of Bern, Bern, Switzerland
} 


\section{Background}

Lung cancer is the leading cause of cancer-related death in industrialized countries [1]. Systemic treatment of lung cancer patients includes chemotherapy, inhibitors of angiogenesis and inhibitors of EGFR signaling. However, since the effect of these drugs is only transient, the overall five-year survival rate is less than $15 \%$. Nonsmall cell lung carcinoma (NSCLC) accounts for $80 \%$ of lung cancer and is further subdivided into two major types, squamous cell carcinoma and adenocarcinoma [2]. Squamous cell carcinoma usually arises from the major bronchi, whereas adenocarcinoma arises from distant airway bronchioles and alveoli. These tumours show frequent alterations of genes involved in cell cycle control or apoptosis including $k-R A S, E G F R, c-M y c$, cyclin D1 (CCND1), TP53, retinoblastoma (Rb), p16INK and $B c l 2$ [3], but the relevant molecular mechanisms driving the aggressive biological behaviour of these tumours are largely unknown.

miRNAs are small regulatory RNA molecules at the post-transcriptional level and are implicated in a wide variety of biological processes including proliferation, differentiation and apoptosis [4]. Notably, miRNAs form networks to regulate the expression of individual components of the cell cycle control machinery. Many of these miRNAs including the let-7 family [5], miR-34 [6], miR-15a/16 [7], miR-221/222 [8,9], miR-17-92 [10], $m i R-107$ and $m i R-185$ [11] are frequently dysregulated in lung cancer and therefore constitute promising targets for specific anticancer intervention (reviewed by Negrini et al. [12]).

Many miRNAs are implicated in cell cycle progression or apoptosis, but surprisingly little information is available if these miRNAs are able to interact with each other to co-ordinately regulate these cellular processes. In addition, it is poorly understood why miRNAs often share common targets despite the fact that they constitute a relatively small family of RNAs encoded by less than 1000 genes. In this study we have analysed two miRNAs, $m i R-15 a / 16$ and $m i R-34$, which are located at chromosomal regions $13 \mathrm{q} 14$ and $1 \mathrm{p} 34$, respectively. Although these miRNAs contain completely unrelated seed sequences, they are functionally related since they are both able to induce $G_{1}-G_{0}$ cell cycle arrest and apoptosis [7,13-15]. In addition, they share common targets including CCND1, CDK4, CDK6, E2F3 and Bcl2. However, other targets also exist which are unique to miR-15a/16 (cyclin E1 (CCNE1), cyclin D2 (CCND2) or cyclin D3 (CCND3)) or miR-34a (c-Myc, n-Myc, and cMet) $[7,16-18]$.

To investigate if these miRNAs are able to interact with each other for the regulation of cellular processes, they were overexpressed in NSCLC cell lines. Here we demonstrate that $m i R-15 a / 16$ and $m i R-34$ act synergistically to induce cell cycle arrest in a Rb-dependent manner. The synergistic effect can be explained by the fact that in concerted action, miRNAs are able to down-regulate more targets than each miRNA alone. Thus, it may be important to analyse miRNAs in a combinatorial mode as this may provide additional information on their role in specific cellular processes. Consistent with these findings, both miRNAs are frequently down-regulated in adenocarcinomas and squamous cell carcinomas of the lung. Our results suggest that targeting a combination of miRNAs involved in the same pathway may potentiate the therapeutic effect of each individual miRNA.

\section{Materials and methods}

\section{Cell lines and culture conditions}

The NSCLC cell lines A549, H2009, H1299 and H358 were obtained from the American Type Culture Collection, Rockville, MD. All cell lines were cultured in Iscove's modified Dulbecco's medium supplemented with $2 \mathrm{mM} \mathrm{L}$-alanyl-L-glutamine, $1 \%$ penicillin/streptomycin and $5 \%$ foetal bovine serum (Sigma) at $37^{\circ} \mathrm{C}$ and $5 \% \mathrm{CO}_{2}$.

\section{Transfection}

Cells were seeded in culture flasks $24 \mathrm{~h}$ prior to transfection. Co-transfections with plasmid DNA were performed using Effectene reagent (Qiagen), all other transfections were performed using HiPerFect (Qiagen). If not otherwise specified, transfection was performed using $20 \mathrm{nM}$ of hsa-pre-miR-34a, a mixture of $10 \mathrm{nM}$ hsa-pre-miR-15a and $10 \mathrm{nM}$ hsa-pre-miR-16 or $20 \mathrm{nM}$ pre-miR miRNA precursor control 1 (Ambion). Si RNAs against Rb, or CCNE1 (siGENOME SMARTpool, Dharmacon) were used at $60 \mathrm{nM}$ or $7.8 \mathrm{nM}$, respectively. Control transfections were performed using non-targeting Pool 2 (siGENOME). pCMV-Rb [19] or empty control plasmid were used at $125 \mathrm{ng} / \mathrm{ml}$. Transfection efficiency of short RNAs and plasmid DNA was monitored using siGloGreen transfection indicator (Dharmacon) or an RFP-expression plasmid, respectively.

\section{Cell cycle analysis and cell death assay}

Cell cycle analysis was performed by flow cytometry essentially as described [7]. For cell death analysis, floating and adherent cells were harvested, combined, washed with PBS and stained with $10 \mu \mathrm{g} / \mathrm{ml}$ propidium idode (Sigma). Apoptotic cells were detected using an antibody directed against cleaved caspase 3 (clone 5A1E, 1:100, Cell Signaling) as described [20]. Cells were analysed using an LSR II flow cytometer (BD Biosciences) and FlowJo 8.8.4 software (Tree Star). As a positive 
control, cells were treated with UV (400 mJ) using a UV Stratalinker 1800 (Stratagene).

\section{RNA isolation and real-time PCR}

Total RNA was extracted from cultured cells using the miRVana RNA isolation kit according to the manufacturer's instructions (Ambion). TaqMan miRNA assays (Applied Biosystems) were performed as described [7] using a Real-Time PCR system 7500 (Applied Biosystems). miRNA levels were normalized to the level obtained for RNU48. Quantification of Bcl2 was done using a TaqMan assay (Applied Biosystems); all other mRNAs were quantified using Quantitec primer assays (Qiagen). mRNA levels were normalized to the level obtained for GAPDH. Changes in expression were calculated using the $\Delta \Delta \mathrm{Ct}$ method.

\section{Western blot analysis}

Western blot analysis was performed as described [7]. Monoclonal antibodies against Rb (clone 3C8, QED Bioscience) and phospho-Rb (Ser807/811, Cell Signaling) were diluted 1:1000, monoclonal antibody against $\mathrm{Bcl} 2$ (clone 124, Dako) was diluted 1:300, and monoclonal antibody against $\alpha$-tubulin (clone B512, Sigma) was diluted 1:5000. Secondary goat anti-mouse-HRP and goat anti-rabbit-HRP antibodies (Biorad) were used at $1: 5000$ or $1: 7000$, respectively.

\section{Laser capture microdissection}

Formalin-fixed paraffin-embedded tissues from 11 adenocarcinomas and 12 squamous cell carcinomas were used for miRNA expression analysis. Tumour tissues and corresponding normal tissues from bronchiolar or alveolar epithelium, respectively, was collected by laser capture microdissection as described previously [7]. Stroma components including connective tissues, inflammatory cells and blood vessels were excluded. Nucleic acids were subjected to a heattreatment in order to remove methylol groups introduced during formalin fixation and subjected to realtime PCR as described [7]. All experiments using human specimens were done according to the ethical guidelines of the Institute of Pathology, University of Bern, and were reviewed by the institutional review board.

\section{Statistics}

Statistical analyses were performed using the GraphPAD prism software. Statistical differences were calculated using unpaired two-tailed student's t-test. A probability of $\mathrm{p} \leq 0.05$ was considered statistically significant. Statistical significance of correlation was assessed by the Pearson test.

\section{Results}

miR-15a/16 and miR-34a are co-regulated in adenocarcinomas of the lung

The finding that $m i R-15 a / 16$ and $m i R-34 a$ share many common targets involved in $\mathrm{G}_{1}$ progression prompted us to analyse if these miRNAs are co-regulated in NSCLC. Tumour tissues of adenocarcinomas and squamous cell carcinomas and matched normal tissues from alveolar or bronchial epithelium, respectively, were collected by laser capture microdissection and compared for the expression of both miRNAs by real-time PCR. We have shown previously that $m i R-15 a$ and $m i R-16$ are frequently down-regulated in NSCLC [7]. Here we demonstrate that the expression of $m i R-16$ is significantly correlated to the expression of $m i R-34 a$ in adenocarcinomas $(p=0.018)$, but not in squamous cell carcinomas of the lung. Both miRNAs were down-regulated in $82 \%(9 / 11)$, and up-regulated in $18 \%(2 / 11)$ of adenocarcinomas (Figure $1 \mathrm{~A}$ ). In contrast, $m i R-34 a$ was significantly down-regulated in 10/12 squamous cell carcinoma samples while $m i R-16$ was down-regulated in 5/ 12 tumour samples. Both miRNAs were also significantly down-regulated in the NSCLC cell lines A549, H2009, H1299 and H358 (data not shown).

Co-repression of miRNAs may be due to defects in miRNA processing. Notably, reduced expression of Dicer has been detected in NSCLC [21]. To address this possibility, the same tumour tissues were analysed for the expression of $m i R-21$, which is frequently up-regulated in lung cancer $[22,23]$. As shown in Figure $1 B$, $m i R-21$ was up-regulated or expressed at normal levels in 9 of 11 adenocarcinomas and 7 of 12 squamous cell carcinomas. Thus, abrogation of miRNA processing may only account for a small subgroup of NSCLC samples.

We next investigated the possibility that both miRNAs are linked because they are able to mutually regulate their expression. To this end, $m i R-15 a / 16$ or $m i R-34 a$ were overexpressed by transfection with miRNA precursors (pre-miRNA) in a Rb-deficient NSCLC cell line, H2009, and analysed for the expression of the miRNA counterpart. Since H2009 is refractory to cell cycle arrest induced by $m i R-15 a / 16$ [7] and $m i R-34 a$ (see below), secondary effects on miRNA expression as a consequence of the $G_{1}-G_{0}$ arrest can be excluded using this cell line. However, neither $m i R-15 a / 16$ nor $m i R-34 a$ was able to affect the expression of its counterpart, while CDK6 mRNA, a target common to both miRNAs, was significantly down-regulated (Figure 1C).

\section{miR-34a-induced cell cycle arrest depends on the expression of $\mathbf{R b}$}

One miRNA can affect the expression of hundreds of proteins [24], which often renders it difficult to identify 


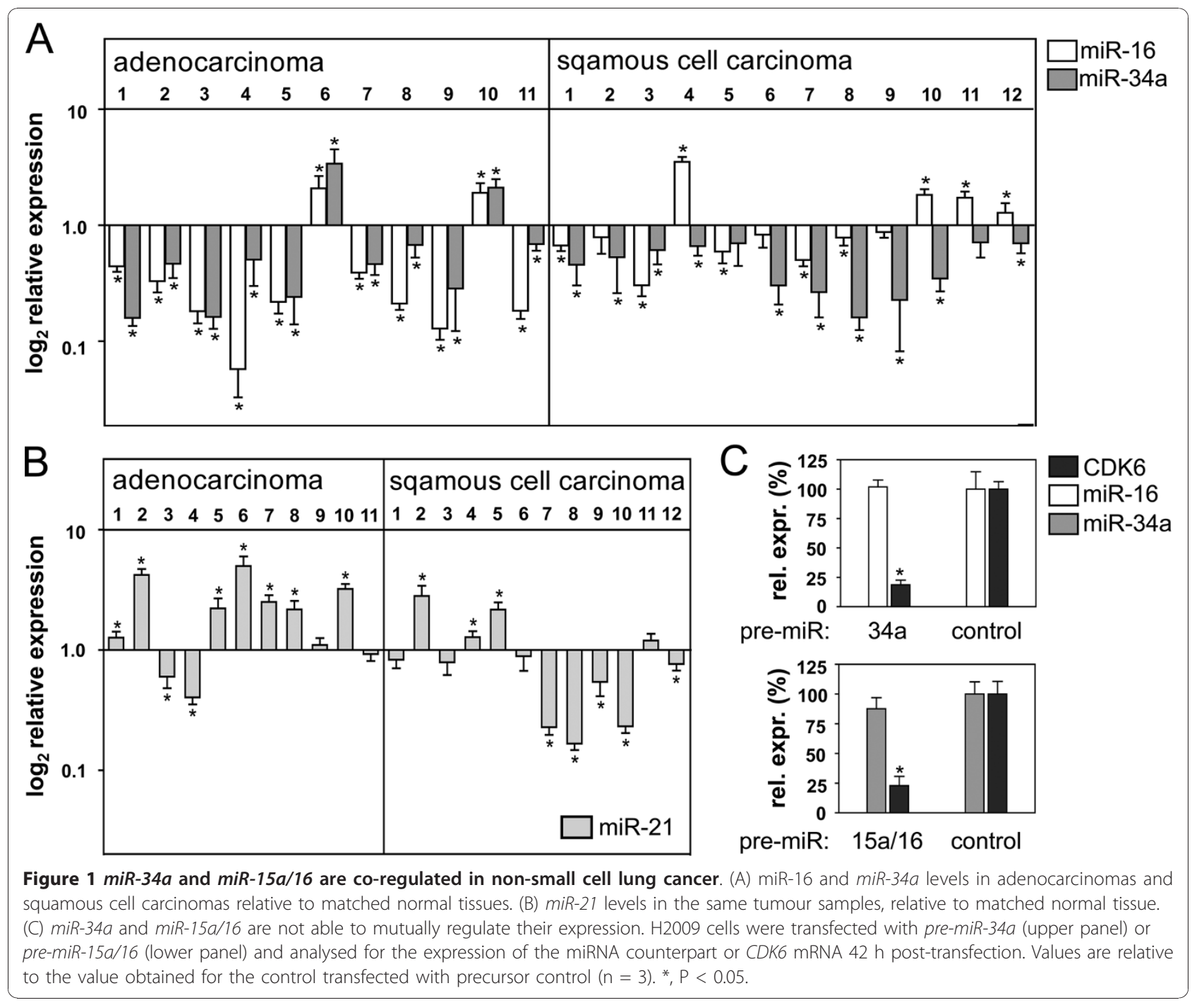

the relevant targets. We have previously shown that miR-15a/16-induced cell cycle arrest depends on the expression of $\mathrm{Rb}$. This indicates that components of the cell cycle machinery upstream of $\mathrm{Rb}$, including cyclin D1 (CCND1), cyclin D3 (CCND3), CDK4 and CDK6 $[7,25,26]$, are the most relevant targets of $m i R-15 a / 16$. To investigate if $m i R 15 a / 16$ and $m i R-34 a$ share redundant functions, $m i R-34 a$ was analysed using the same set of experiments as we have described previously for miR-15a/16 [7].

To investigate cell cycle arrest, the NSCLC cell lines A549, H358, H1299 and H2009 were transfected with pre-miRNA-34a and treated with nocodazole $24 \mathrm{~h}$ post-transfection. Nocodazole traps cells at the $\mathrm{G}_{2}-\mathrm{M}$ phase, but $\sim 30 \%$ of the transfected A $549, \mathrm{H} 358$ or H1299 cells accumulated in $\mathrm{G}_{1}-\mathrm{G}_{0}$ (Figure 2A and $2 \mathrm{~B}$ ) indicating that $m i R-34 a$ induces an arrest in this phase of the cell cycle. In contrast, $\mathrm{Rb}$-deficient
H2009 cells were completely refractory to $m i R-34 a$ induced arrest (Figure 2A and 2B). However, known targets of miR-34a including CDK4, CDK6, CCND1 and $c$-Met were significantly down-regulated in these cells (Figure $2 \mathrm{C}$ ). $\mathrm{Rb}$ reconstitution into $\mathrm{Rb}$-deficient NSCLC lines restores $G_{1}$ arrest mechanisms [27]. To investigate if $m i R$-34a-induced cell cycle arrest depends on the expression of $\mathrm{Rb}$, the latter gene was reintroduced into $\mathrm{H} 2009$ cells. Co-transfection of H2009 cells with pre-miR-34a and an empty control plasmid induced cell cycle arrest in $3.1 \pm 1 \%$ of the population (Figure 3A). Consistent with previous findings [27], the percentage of cells in the $G_{1}-G_{0}$ phase of the cell cycle increased to $16 \pm 1 \%$ upon transfection with a $\mathrm{Rb}$ expression plasmid $(\mathrm{p}=0.001)$. This indicates that $\mathrm{Rb}$ per se is able to induce cell cycle arrest in a significant proportion of the population. However, $\mathrm{Rb}$ plasmid in combination with pre-miR- 

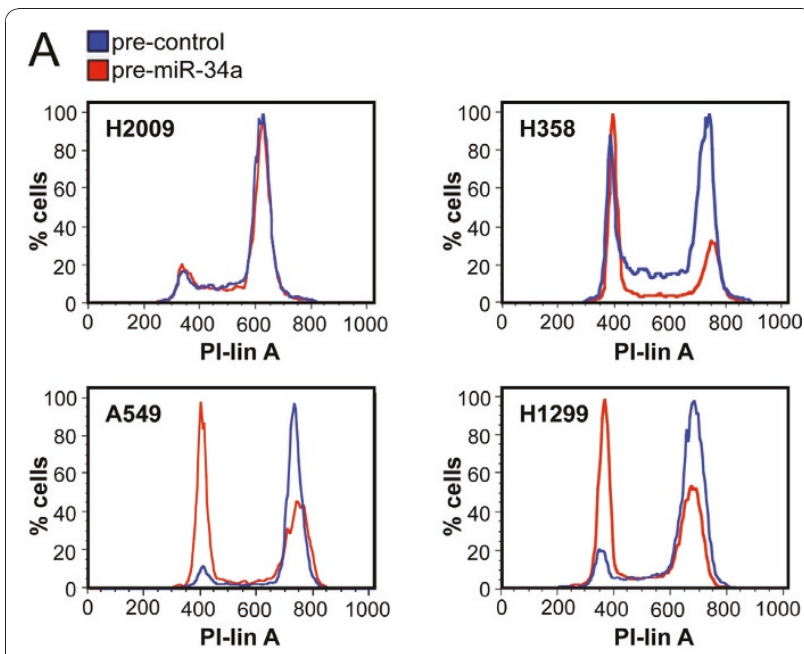

B
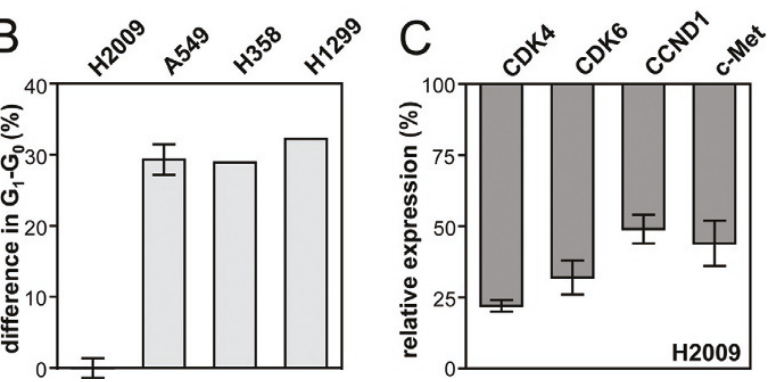

Figure $2 \mathrm{H} 2009$ cells are refractory to $m i R-34 a$-induced cell cycle arrest. (A) DNA content distribution of NSCLC cells transfected with precursor miRNA or precursor control. Cells were treated for $18 \mathrm{~h}$ with nocodazole beginning $24 \mathrm{~h}$ post-transfection. (B) Percent difference in $G_{1}-G_{0}$ between cells transfected with premiR-34a and cells transfected with precursor control. H2009, A549, n $=3 ; \mathrm{H} 1299$ and $\mathrm{H} 358, \mathrm{n}=1$. (C) mRNA levels of known miR-34a targets. H2009 cells were transfected with pre-miR-34a and harvested $42 \mathrm{~h}$ post-transfection $(n=3)$. Values are relative to the level obtained for the control transfected with precursor control.

$34 a$ induced cell cycle arrest in significantly more cells $(26 \pm 1 \%, \mathrm{p}=0.01)$ than $\mathrm{Rb}$ plasmid in combination with the precursor control. The expression of Rb protein was not affected by pre-miR-34a. In contrast, phospho- $\mathrm{Rb}$ was reduced by $50 \%$ under these conditions (Figure 3B). In conclusion, the ability of miR-34a to induce cell cycle arrest depends on the expression of Rb. Complementary experiments were performed in A549 cells, in which the $\mathrm{Rb}$ gene was knocked down by RNA interference. The knock-down expressed three times less $\mathrm{Rb}$ protein than the control (Figure 3C). As expected, the knock-down was significantly more resistant to $m i R$-34a-induced cell cycle arrest $\left(22 \pm 1 \%\right.$ in $\left.\mathrm{G}_{1}-\mathrm{G}_{0}\right)$ than the control $\left(43 \pm 1 \%\right.$ in $\mathrm{G}_{1}$ $\mathrm{G}_{0}, \mathrm{p}<0.001$ ) (Figure 3D). In conclusion, there is a significant degree of redundancy between $m i R-34 a$ and $m i R-15 a / 16$ in their ability to induce cell cycle arrest in NSCLC cells.

\section{miR-15a/16 and miR-34a act synergistically to induce} arrest in $\mathrm{G}_{1}-\mathrm{G}_{0}$

We next addressed the question if $m i R-15 a / 16$ and $m i R$ $34 a$ act together to induce cell cycle arrest. A549 cells were transfected with increasing concentrations of pre$m i R-15 a / 16$ or pre-miR-34a and analysed for cell cycle arrest (Figure 4A). From the slope of the dose-response curves it can be deduced that pre-miR-34a was more efficient than pre-miR-15a/16 in inducing cell cycle arrest. We next assessed the concerted action of $m i R$ $15 a / 16$ and $m i R-34 a$ precursors on cell cycle arrest. Transfection with $2.5 \mathrm{nM}$ pre-miR-15/16 or transfection with $0.63 \mathrm{nM}$ pre-miR-34a resulted in a $\mathrm{G}_{1}-\mathrm{G}_{0}$ arrest of A549 cells in $10.9 \pm 0.6 \%$ and $20.1 \pm 1.6 \%$ of the population, respectively. Interestingly, a mixture with half the concentrations of pre-miR-15/16 and pre-miR-34a was more efficient $(25.9 \pm 2.2 \%)$ than each pre-miRNA alone in inducing a $\mathrm{G}_{1}-\mathrm{G}_{0}$ arrest, $\mathrm{p} \leq 0.02$ (Figure $4 \mathrm{~A}$ ). Consistent results were obtained over a four-fold concentration range. Thus, these results clearly indicate that $m i R-15 a /$ 16 and $m i R-34 a$ act synergistically to induce cell cycle arrest in $\mathrm{G}_{1}-\mathrm{G}_{0}$.

Both pre-miRNAs displayed saturation for cell cycle arrest at a concentration of $20 \mathrm{nM}$ (data not shown). Interestingly, a synergistic effect was also obtained at this concentration: cells transfected with $20 \mathrm{nM}$ premiR-15a/16 or $20 \mathrm{nM}$ pre-miR-34a in each case gave rise to a $G_{1}-G_{0}$ arrest in about $37 \%$ of the population. In contrast, co-transfection of cells with both pre-miRNAs at half the concentration (10 $\mathrm{nM}$ each) resulted in a $\mathrm{G}_{1}-\mathrm{G}_{0}$ arrest in $54.6 \pm 2.2 \%$ of the population (Figure $4 \mathrm{~B}, 24 \mathrm{~h}), \mathrm{p}<0.0005$. The synergistic effect was observed $24 \mathrm{~h}$ and $48 \mathrm{~h}$ post-transfection (Figure $4 \mathrm{~B}$ ).

\section{No synergistic action on cell death}

$m i R-15 a / 16$ and $m i R-34 a$ are both able to down-regulate the anti-apoptotic protein $B c l 2$ (Figure $5 \mathrm{~A}$ ). In addition, both miRNAs have been shown to induce apoptosis in different cell systems $[13,15]$. We therefore wondered if these miRNAs also act synergistically to induce apoptosis. In line with previous findings we were unable to detect any significant increase in propidium iodide (PI)-positive A549 or H2009 cells on transfection with $m i R-15 a / 16$ (Figure 5B and Additional file 1). Likewise, no significant increase in cleaved caspase-3-positive cells was observed (Figure 5C). In contrast, miR-34a elicited a 2-3-fold increase in PI-positive cells and an eight-fold increase in cleaved caspase-3-positive cells 72$96 \mathrm{~h}$ post-transfection (Figure 5B and 5C). Surprisingly, a mixture of both pre-miRNAs at half the concentration was less efficient than miR-34a alone in inducing cell death. In conclusion, no synergism elicited by $m i R-15 a /$ 16 and miR-34a exists for cell death in NSCLC cells. 

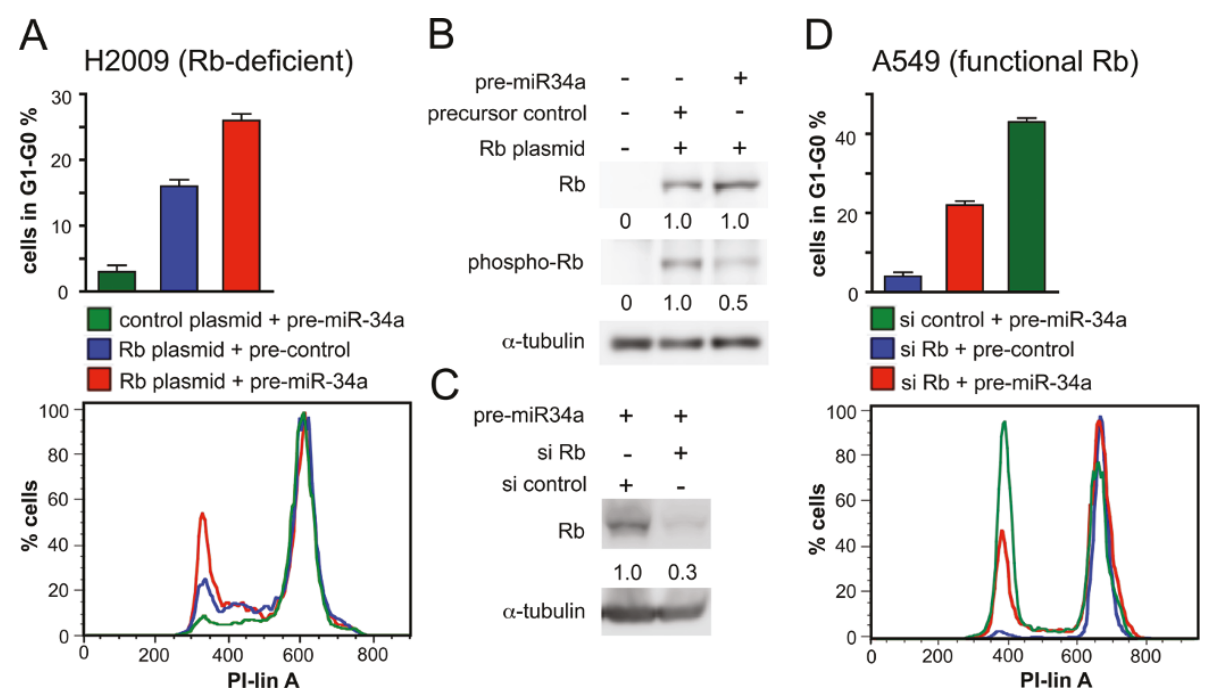

Figure 3 miR-34a-induced cell cycle arrest depends on the expression of Rb. (A, D), DNA content distribution by flow cytometry of H2009 (A) and A549 cells (D) treated for $18 \mathrm{~h}$ with nocodazole beginning $48 \mathrm{~h}$ post-transfection. The percent cells in $G_{1}-G_{0}$ is shown in the upper panel $(n=3)$ and a representative histogram of the cell cycle profile is shown in the lower panel. $(B, C)$, Western blot analysis of H2009 (B) and A549 cells (C) subjected to the same conditions as in (A) and (D) using antibodies directed against Rb or phospho-Rb. Protein levels were normalised to $\alpha$-tubulin.

\section{Combined action of $m i R-15 a / 16$ and $m i R-34 a$ on the stability of individual mRNA targets}

We next investigated the mechanism underlying the synergistic action of $m i R-34 a$ and $m i R-15 a / 16$. It is possible that the observed effect is due to a more efficient down-regulation of targets common to both miRNAs by a combined action of $m i R-34 a$ and $m i R-15 a / 16$. To circumvent adverse secondary effects on target gene expression of individual $\mathrm{G}_{1}$ proteins as a consequence of cell cycle arrest, the cell line $\mathrm{H} 2009$ was again used for the experiment. Transfection with serial dilutions of pre-miRNAs allowed the establishment of a direct relationship between the amount of input pre-miRNA and the steady-state level of mRNA of the target genes
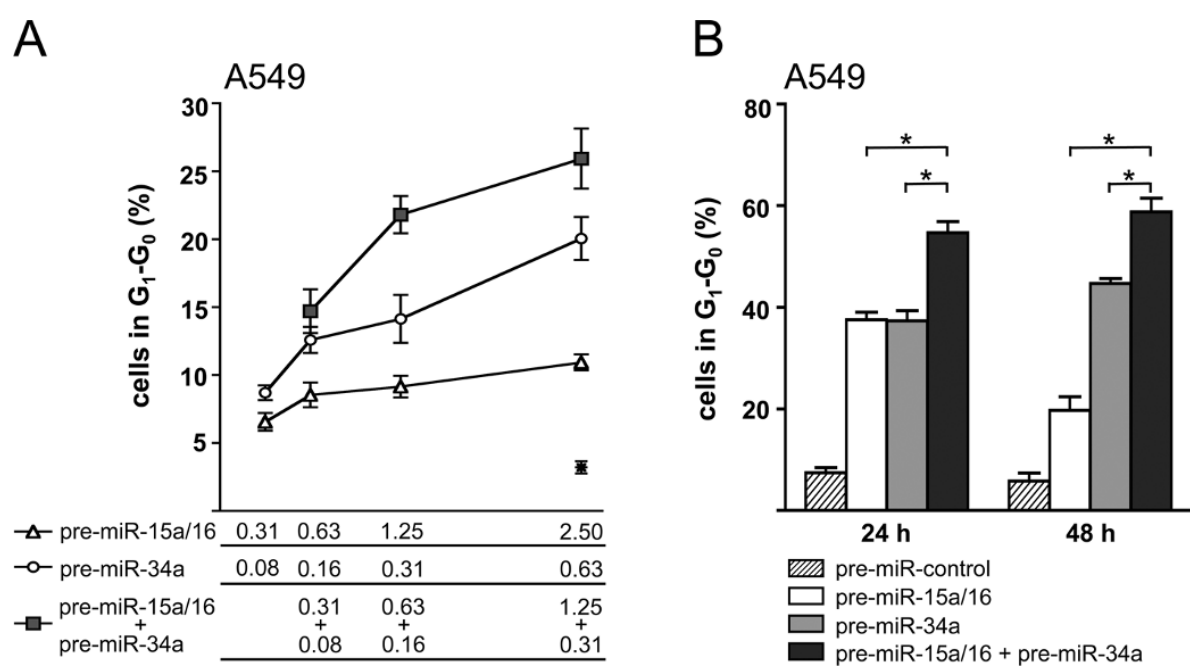

Figure 4 miR-15a/16 and miR-34a act synergistically to induce cell cycle arrest. (A) Cell cycle analysis of A549 cells transfected with premiR-34a and/or pre-miR-15a/16 under non-saturating conditions. Precursors were supplemented with precursor control to yield a total concentration of $2.5 \mathrm{nM}$ per transfection. *, transfection with $2.5 \mathrm{nM}$ precursor control. Cells were treated for $18 \mathrm{~h}$ with nocodazole beginning 24 h post-transfection $(n=3)$. (B) Cell cycle analysis under saturating conditions. A549 cells were transfected with 20 nM precursor or precursor control or co-transfected with $10 \mathrm{nM}$ pre-miR-34a and $10 \mathrm{nM}$ pre-miR-15a/16 and treated for $18 \mathrm{~h}$ with nocodazole beginning $24 \mathrm{~h}$ (left panel) or $48 \mathrm{~h}$ (right panel) post-transfection $(\mathrm{n}=3)$. 


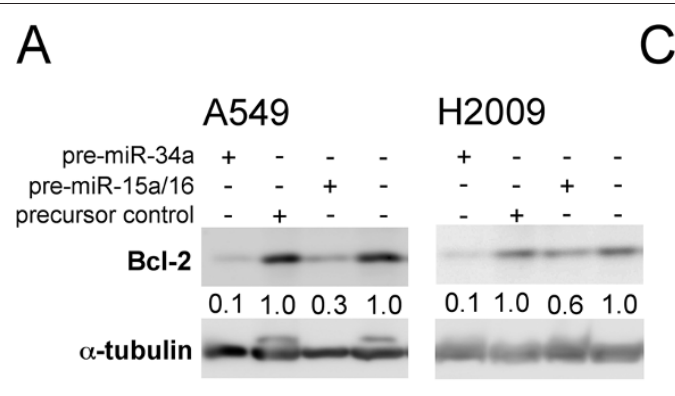

B
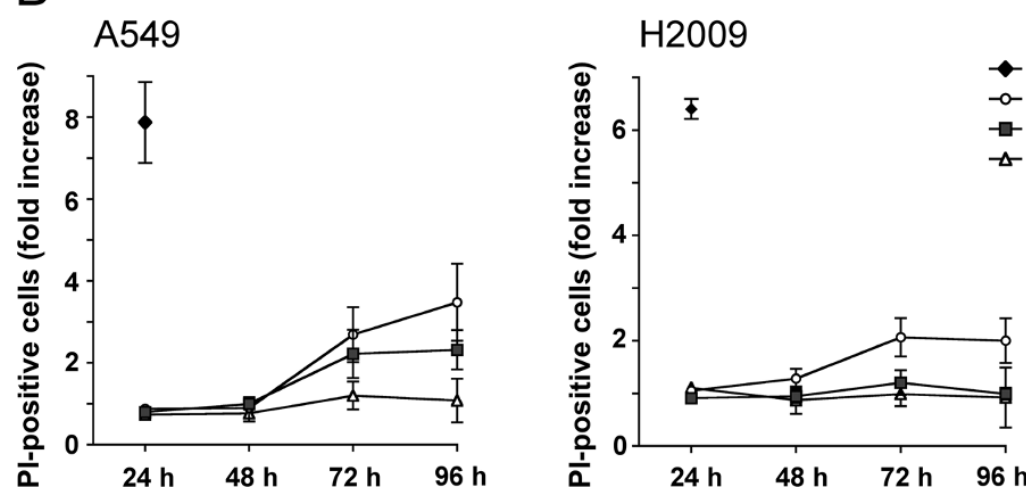

Figure 5 No synergism on cell death. (A) Bcl2 expression. A549 or H2009 cells were transfected with 20 nM precursors and harvested 42 h post-transfection. Western blot analysis was performed using a monoclonal antibody against Bcl2. Protein levels were normalized to $\alpha$-tubulin and presented relative to the level obtained for the control. (B) Time-course of propidium iodide (PI)-positive A549 and H2009 cells by flow cytometry. Cells were transfected with concentrations of precursors as indicated in the legend to Fig. 4B $(n=3)$. Cells were gated as shown in Additional file 1A. (C) Cleaved caspase-3-positive cells. H2009 cells were analysed for the presence of cleaved caspase 3 by flow cytometry 72 h post-transfection $(n=3)$. Values are relative to the level obtained for the control transfected with precursor control. As a positive control, cells were treated with UV.

CDK4, CDK6 and CCND1, respectively (Figure 6A and Additional file 2).

Interestingly, transfection of $\mathrm{H} 2009$ cells with miR-34a or $m i R-15 a / 16$, or co-transfection of $\mathrm{H} 2009$ cells with a mixture of both pre-miRNAs at half the concentration gave rise to comparable dose-response curves for all the three target genes (Figure 6A). From these results we may conclude that $m i R-15 a / 16$ and $m i R-34 a$ act in an additive rather than in a synergistic manner on individual mRNAs. Comparable results were obtained in H2009 and A549 cells excluding the possibility that the concerted action on individual mRNA targets depends on the expression of $\mathrm{Rb}$ (data not shown).

The synergistic action of $m i R-15 a / 16$ and $m i R-34 a$ is due to the down-regulation of additional genes involved in $\mathrm{G}_{1}$ progression

Although $m i R-15 a / 16$ and $m i R-34 a$ share many common targets, other targets exist which are unique to $m i R-15 a / 16$ or $m i R-34 a$ (Additional file 2). Since no synergistic effect was observed for individual mRNA targets, we hypothesized that the observed effect may be due to the fact that more targets involved in $G_{1}-S$ progression are repressed by the combined action of both miRNAs. Target specificity was re-evaluated using the cell line $\mathrm{H} 2009$, which is refractory to miRNAinduced arrest. In agreement with reports from the literature $[7,16]$, down-regulation of $c$-Met mRNA was specific for $m i R-34 a$, whereas down-regulation of CCND3 and CCNE1 mRNAs were specific for miR-15a/ 16 (Figure 6B and Additional file 2). In contrast, CCNE2 mRNA, which contains a target site for $m i R-34 a$ [16], and CCNA1 mRNA, which contains no target site, were virtually unaffected.

To address the possibility that the synergistic effect was due to an increased number of targets, CCNE1, a target unique to $m i R-15 a / 16$ (Figure $6 \mathrm{~B}$ and Additional file 2), was knocked down in A549 cells by RNA interference resulting in $80.3 \pm 6.6 \%$ less CCNE1 mRNA. We would expect that the synergistic effect would be reduced under these conditions, given that one of the unique targets, CCNE1, has been removed. This was indeed the case. The percentage of cells in the $G_{1}-G_{0}$ phase increased to $36 \%$ on co-transfection with CCNE1 siRNA and pre-miR-control (Figure 7A, striped columns). However, CCNE1 siRNA had only a low impact on cell cycle arrest of cells 


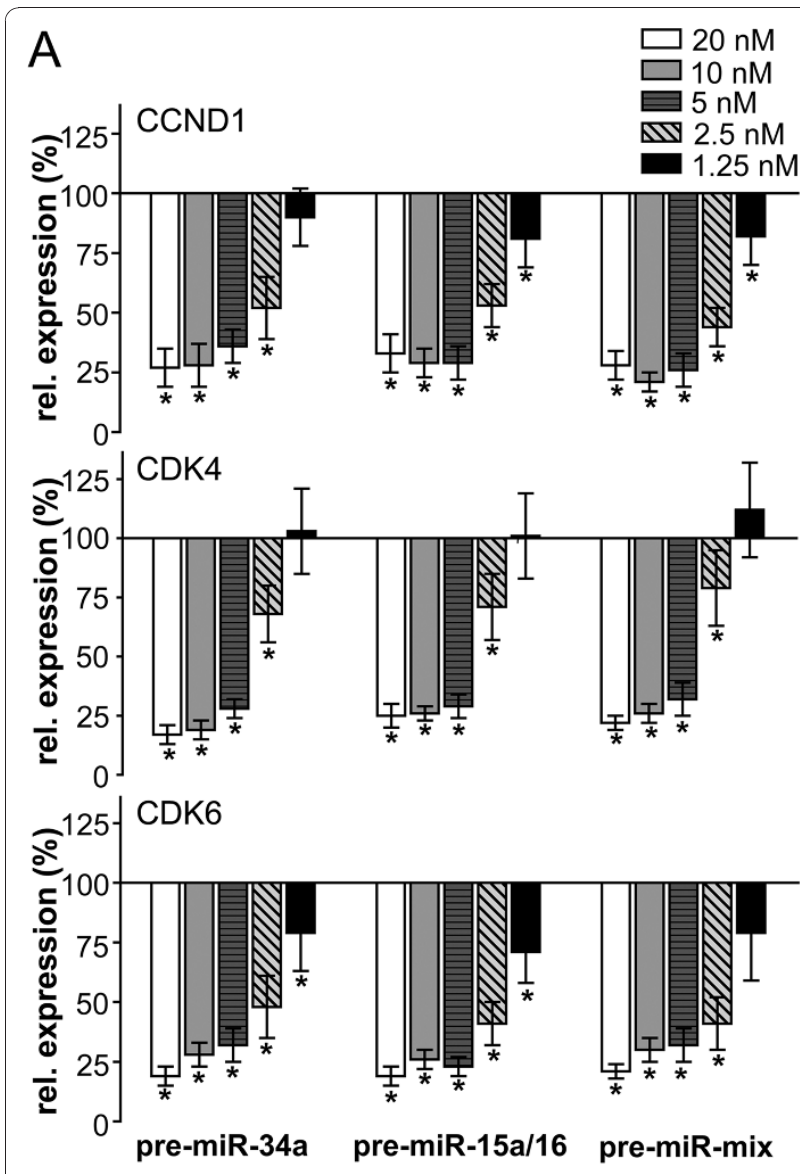

B

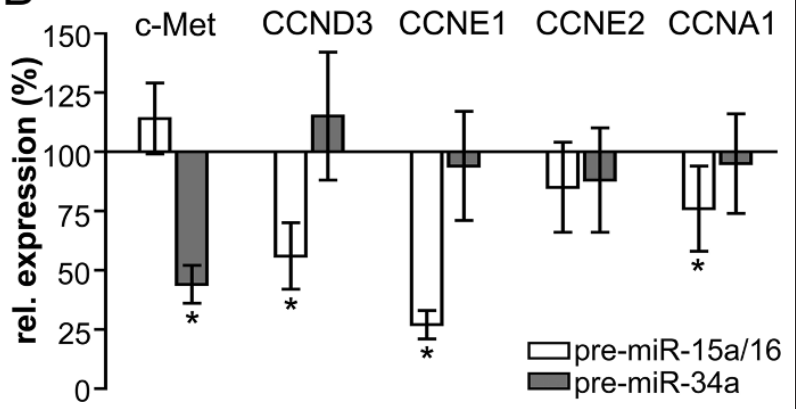

Figure 6 Concerted action of $m i R-15 a / 16$ and $m i R-34 a$ on individual mRNA targets. (A) mRNA levels of targets common to both miRNAs. H2009 cells were transfected with pre-miR-15a/16 or pre-miR-34a alone or co-transfected with both pre-miRNAs together (pre-miR-mix) at concentrations as indicated in the figure. (B) Expression level of targets unique to miR-15a/16 or miR-34a. Analysis was performed as described in the legend to Fig. $2 C(n=3) .{ }^{*}, p<$ 0.05

overexpressing miR-15a/16 (Figure 7A, white columns), which can be explained by the fact that $C C N E 1$ was already down-regulated by $m i R-15 a / 16$. In contrast, the percentage of A549 cells in $\mathrm{G}_{1}-\mathrm{G}_{0}$ increased almost two-fold on cotransfection with pre-miR-34a and CCNE1 siRNA relative
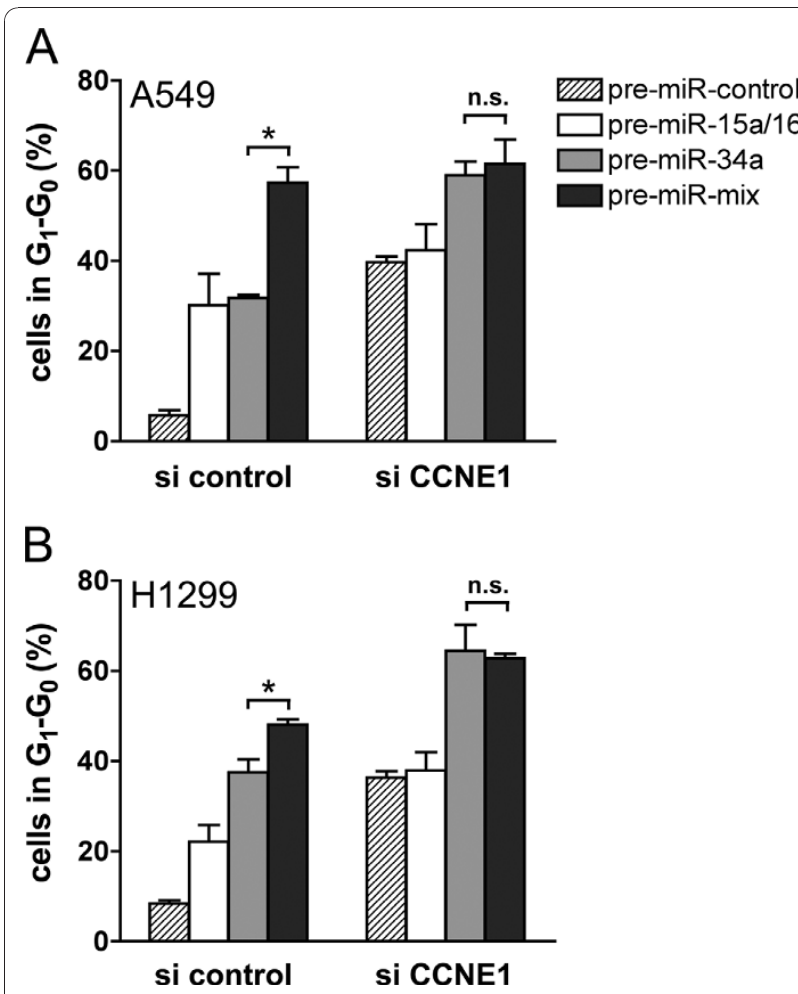

Figure 7 Synergistic action on cell cycle arrest is due to the down-regulation of unique mRNA targets. A549 (A) or H1299 cells (B) were co-transfected with $20 \mathrm{nM}$ miRNA precursors and 7.8 $\mathrm{nM}$ siRNA against CCNE1 and subsequently treated for $18 \mathrm{~h}$ with nocodazole beginning $24 \mathrm{~h}$ post-transfection. Comparable results were also obtained $48 \mathrm{~h}$ post-transfection (data not shown).

to cells co-transfected with pre-miR-34a and si control (Figure 7A, grey columns), suggesting that CCNE1 siRNA and pre-miR-34a act together to induce cell cycle arrest in a more efficient manner. Notably, CCNE1 siRNA in combination with pre-miR-34a (59.0 $\pm 3.1 \%$; grey column) and CCNE1 siRNA in combination with both pre-miRNAs (61.6 $\pm 5.3 \%$; black column; $p=0.5)$ induced $a G_{1}-G_{0}$ arrest with the same efficiency. Thus, the synergistic effect exerted by the combined action of $m i R-15 a / 16$ and $m i R$ $34 a$ was clearly abrogated. In contrast, si control in combination with both pre-miRNAs together gave rise to almost two times more cells in $\mathrm{G}_{1}-\mathrm{G}_{0}$ than si control in combination with pre-miR-34a or pre-miR-15a/16, respectively $(\mathrm{p}<$ $0.004)$. The observed effects were not cell-line-specific, since comparable results were obtained for A549 (Figure 7A) and H1299 cells (Figure 7B). In conclusion, the synergistic effect of $m i R-15 a / 16$ and $m i R-34 a$ is due to the fact that more miRNA targets are down-regulated by the combined action of both miRNAs.

\section{Discussion}

Cell cycle progression critically depends on numerous regulatory processes which are often deregulated in 
cancer (reviewed by Evan et al. [28]). miRNAs contribute to the complexity of cell cycle control by interfering with a variety of different components of the cell cycle machinery allowing the coordinated regulation of gene expression at the post-transcriptional level (reviewed by Bueno et al. [29] and Carleton et al. [30]).

$m i R-15 a / 16$ and $m i R-34 a$ share overlapping functions. They both induce cell cycle arrest in $\mathrm{G}_{1}-\mathrm{G}_{0}$ and share common targets including CCND1, CDK4 and CDK6. In addition, the ability of either one of these miRNAs to induce cell cycle arrest in $G_{1}-G_{0}$ largely depends on the expression of Rb (Figure 3 and ref. [7]). Cyclin D in complexes with CDK4 or CDK6, and cyclin $\mathrm{E}$ in a complex with $\mathrm{CDK} 2$ regulate progression through the $\mathrm{G}_{1}-\mathrm{S}$ boundary of the cell cycle. These complexes phosphorylate and thereby prevent $\mathrm{Rb}$ from binding to $\mathrm{E} 2 \mathrm{~F}$, which on release, drives cells from $G_{1}$ to $S$ phase (reviewed by Morgan et al. [31]). From these results we may conclude that functionally relevant targets of either type of miRNA must be upstream of Rb. These include CCNE1 and CCND3, which are unique to miR-15a/16, c-Myc and c-Met, which are unique to $m i R-34 a$ and CCND1, CDK4 and CDK6, which are common to both miRNAs. With the exception of CDK4 and c-Myc, all these genes are confirmed targets of $m i R-15 a / 16$ and $m i R-34 a$ in NSCLC cells $[7,14,16,26]$. In contrast, experimentally validated targets downstream of $\mathrm{Rb}$ including E2F1, E2F2, E2F3, E2F7, WEE1, CHK1 and CARD10 $[25,32,33]$ seem to be less relevant for the regulation of cell cycle progression by $m i R-15 a / 16$ or $m i R-34 a$, at least in NSCLC cells.

The finding that both miRNAs share highly related functions is further illustrated by the fact that both miRNAs are co-regulated in all adenocarcinoma samples. In the majority of NSCLC cases, both miRNAs are significantly down-regulated indicating that they play an important role as tumour suppressor. Tumours can escape the concerted action of $m i R-15 a / 16$ and $m i R-34 a$ by down-regulation of both miRNAs or, alternatively, by down-regulation of Rb. Mechanisms which may lead to dysregulation of miR-15a/ 16 or $m i R-34 a$ in cancer include deletion of the respective miRNA loci $[7,34]$, defects in miRNA processing [21], altered promoter methylation [35], or altered expression of transcriptional regulators [36-38]. Defects in miRNA processing may account for only a subgroup of NSCLC, since the majority of tumours either expressed normal or high levels of miR-21. p53 is a potent transactivator of miR-34a $[39,40]$, and is implicated in the processing of miR-16 [40]. However, no correlation was observed between the mutation status of $\mathrm{p} 53$ and the expression level of miR-34a [6] or miR-15a/16 [41]. In addition, the possibility that both miRNAs are able to mutually regulate their expression can be excluded (Figure 1C). Thus, it rather seems that several independent mechanisms may account for the dysregulation of $m i R-15 a / 16$ and $m i R-34 a$ in NSCLC.

Why is there a relatively high degree of redundancy between miRNAs? To address this question we co-transfected cells with miR-15a/16 and miR-34a and demonstrated that both miRNAs act synergistically to induce cell cycle arrest in $G_{1}-G_{0}$. In contrast, the concerted action of these miRNAs on common mRNA targets was additive rather than synergistic. Thus, there seems to be little interference in binding of these miRNAs to the same target molecule and each miRNA contributes to the mRNA stability in an independent manner. The synergistic effect can rather be explained by the fact that in addition to their targets common to both miRNAs they are also able to bind to targets unique to either type of miRNA. Thus, in a combinatorial mode, both miRNAs are able to down-regulate more targets than each miRNA alone. This is based on the finding that knocking down $C C N E 1$, a target unique to $m i R-15 a / 16$, by RNA interference, abrogated the synergistic effect exerted by the combination of both miRNAs (Figure 7). These effects were not cell-line-specific, since comparable results were obtained with A549 and H1299 cells. This model is in agreement with our results that $m i R-34 a$ and $m i R-15 a /$ 16 acted synergistically under both saturating and nonsaturating conditions. In contrast, if the synergistic effect of these miRNAs were due to a more efficient repression of individual targets, we would expect such an effect to occur only under non-saturating conditions. miRNAs exert fine-tuning regulatory functions, in most cases leading only to a modest repression of target mRNAs and proteins [24]. Our results suggest that miRNAs can potentiate their impact on the regulation of cellular processes by acting in a combinatorial mode.

Surprisingly, we were unable to detect any synergistic effect on apoptosis. Although both miRNAs are able to target $B c l 2$, only $m i R-34 a$ was able to induce apoptosis. This may be due to quantitative differences in their ability to down-regulate $B c l 2$. Alternatively, other anti-apoptotic genes besides $B c l 2$, which are targeted by $m i R-34 a$, but not $m i R-15 a / 16$, may have to be down-regulated in order apoptosis can occur. It is noteworthy, however, that the observed effects may depend on the cell system as $m i R-15 a / 16$ was able to induce apoptosis in CLL [15].

There are only few examples of miRNAs in the literature that act in a synergistic manner. Ivanosvska and Cleary were the first to investigate the concerted action of miR16 and miR-34a on cell cycle arrest. However, based on their results it was not clear if both miRNAs acted in an additive or synergistic manner [42]. miR-84 and let-7 promote terminal differentiation of the hypodermis and cessation of molting in C. elegans in a synergistic manner [43]. However, miR-84 and let-7 share identical seed sequences, suggesting that they regulate the same set of target genes. 
In addition, pairs of a cytomegalovirus derived miRNA and a host cell derived miRNA acted on the same gene $(M I C B)$ through site proximity in a synergistic manner [44]. Thus different mechanisms may exist that may lead to a synergistic action of miRNAs.

Therapeutic strategies for the treatment of human cancer based on modulation of miRNA activity in cancer tissues have gained much attention in the past few years $[12,45-49]$. In a recent publication, a new formulation is described that allows the reintroduction of miRNAs, depleted in cancer cells, in order to reactivate cellular pathways that drive a therapeutic response [50]. The authors demonstrated that formulated $m i R-34 a$ blocked tumour growth in a mouse model of NSCLC. Our results suggest that administering formulated miR$34 a$ in combination with formulated $m i R-15 a / 16$ may lead to a significant increase in the therapeutic impact. This strategy may be particularly effective for the treatment of NSCLC, since both types of miRNAs are normally down-regulated in this class of tumours.

\section{Conclusion}

It is generally agreed that miRNAs form part of networks to control cellular processes. Currently, the miRNA field is focused primarily on the identification of novel targets of individual miRNAs, but little information is available how miRNAs act in a combinatorial mode. We show that $m i R-34 a$ and $m i R-15 a / 16$ act together to control cell cycle progression in a synergistic and $\mathrm{Rb}$-dependent manner. From these results we may conclude that the combination of miRNAs, which form part of the same network, rather than individual miRNAs should be considered for assessing a biological response. In addition, our study may have translational implications. Since both miRNAs are significantly downregulated in the majority of adenocarcinomas, administering a combination of both miRNAs may potentiate the therapeutic impact of each individual miRNA.

\section{Additional material}

Additional file 1: Analysis of propidium iodide (PI)-stained cells by flow cytometry. H2009 and A549 cells were transfected as described in the legends to Figure 5 and analysed $72 \mathrm{~h}$ or $96 \mathrm{~h}$ post-transfection, respectively. (A) dot plot of FSC vs. PI (log) of the transfection experiments in Figure 5B. (B) percent Pl-positive cells. The mean \pm SD from independent transfections is presented $(n \geq 3)$.

Additional file 2: Schematic depiction of the $3^{\prime}$ untranslated region of $m i R-15 a / 16$ and $m i R-34 a$ targets. miR-15a/16-specific target sites are highlighted in red and miR-34a-specific target sites are highlighted in blue. CCND1, CCND2, CCND3, CCNE1, CDK4, C-MET and BCI2 are experimentally validated targets and CDK6 and C-MYC are predicted targets of miR-15a/16 and miR-34a in NSCLC cell lines. CCNA1 contains no miR-15a/16 or miR-34a-specific target sites.

\section{Acknowledgements}

We thank Thomas Brunner for helpful discussions and critical reading of the manuscript.

This work was supported by a grant from the Swiss National Science Foundation to EV.

\section{Authors' contributions}

NB performed all experiments, participated in the conception and design of the study and helped to draft the manuscript. EV was responsible for the conception and design of the study and wrote the manuscript. Both authors read and approved the final manuscript.

\section{Competing interests}

The authors declare that they have no competing interests.

Received: 19 November 2010 Accepted: 16 May 2011

Published: 16 May 2011

\section{References}

1. Edwards BK, Brown ML, Wingo PA, Howe HL, Ward E, Ries LA, Schrag D, Jamison PM, Jemal A, Wu XC, Friedman C, Harlan L, Warren J, Anderson RN, Pickle LW: Annual report to the nation on the status of cancer, 19752002, featuring population-based trends in cancer treatment. $J$ Natl Cancer Inst 2005, 97:1407-1427.

2. Gazdar AF: Lung cancer preneoplasia. Annu Rev Pathol 2006, 1:331-348.

3. Fong KM, Sekido Y, Gazdar AF, Minna JD: Lung cancer. 9: Molecular biology of lung cancer: clinical implications. Thorax 2003, 58:892-900.

4. Hwang HW, Mendell JT: MicroRNAs in cell proliferation, cell death, and tumorigenesis. Br J Cancer 2006, 94:776-780.

5. Takamizawa J, Konishi H, Yanagisawa K, Tomida S, Osada H, Endoh H, Harano T, Yatabe Y, Nagino M, Nimura Y, Mitsudomi T, Takahashi T: Reduced expression of the let-7 microRNAs in human lung cancers in association with shortened postoperative survival. Cancer Res 2004, 64:3753-3756.

6. Gallardo E, Navarro A, Vinolas N, Marrades RM, Diaz T, Gel B, Quera A, Bandres E, Garcia-Foncillas J, Ramirez J, Monzo M: miR-34a as a prognostic marker of relapse in surgically resected non-small-cell lung cancer. Carcinogenesis 2009, 30:1903-1909.

7. Bandi N, Zbinden S, Gugger M, Arnold M, Kocher V, Hasan L, Kappeler A, Brunner T, Vassella E: miR-15a and miR-16 are implicated in cell cycle regulation in a $\mathrm{Rb}$-dependent manner and are frequently deleted or down-regulated in non-small cell lung cancer. Cancer Res 2009, 69:5553-5559.

8. Garofalo M, Di Leva G, Romano G, Nuovo G, Suh SS, Ngankeu A, Taccioli C, Pichiorri F, Alder H, Secchiero P, Gasparini P, Gonelli A, Costinean S, Acunzo M, Condorelli G, Croce CM: miR-221\&222 regulate TRAIL resistance and enhance tumorigenicity through PTEN and TIMP3 downregulation. Cancer Cell 2009, 16:498-509.

9. Frenquelli M, Muzio M, Scielzo C, Fazi C, Scarfo L, Rossi C, Ferrari G, Ghia P, Caligaris-Cappio F: MicroRNA and proliferation control in chronic lymphocytic leukemia: functional relationship between miR-221/222 cluster and p27. Blood 2010, 115:3949-3959.

10. Hayashita Y, Osada H, Tatematsu Y, Yamada H, Yanagisawa K, Tomida S, Yatabe Y, Kawahara K, Sekido Y, Takahashi T: A polycistronic microRNA cluster, miR-17-92, is overexpressed in human lung cancers and enhances cell proliferation. Cancer Res 2005, 65:9628-9632.

11. Takahashi Y, Forrest AR, Maeno E, Hashimoto T, Daub CO, Yasuda J: MiR107 and MiR-185 can induce cell cycle arrest in human non small cell lung cancer cell lines. PLoS One 2009, 4:e6677.

12. Negrini M, Ferracin M, Sabbioni S, Croce CM: MicroRNAs in human cancer: from research to therapy. I Cell Sci 2007, 120:1833-1840.

13. Hermeking H: The miR-34 family in cancer and apoptosis. Cell Death Differ 2010, 17:193-199.

14. Sun F, Fu H, Liu Q, Tie Y, Zhu J, Xing R, Sun Z, Zheng X: Downregulation of CCND1 and CDK6 by miR-34a induces cell cycle arrest. FEBS Lett 2008, 582:1564-1568.

15. Cimmino A, Calin GA, Fabbri M, lorio MV, Ferracin M, Shimizu M, Wojcik SE, Aqeilan Rl, Zupo S, Dono M, Rassenti L, Alder H, Volinia S, Liu CG, Kipps TJ, 
Negrini M, Croce CM: miR-15 and miR-16 induce apoptosis by targeting BCL2. Proc Natl Acad Sci USA 2005, 102:13944-13949.

16. He L, He X, Lim LP, de Stanchina E, Xuan Z, Liang Y, Xue W, Zender L, Magnus J, Ridzon D, Jackson AL, Linsley PS, Chen C, Lowe SW, Cleary MA, Hannon GJ: A microRNA component of the p53 tumour suppressor network. Nature 2007, 447:1130-1134.

17. Cannell IG, Kong YW, Johnston SJ, Chen ML, Collins HM, Dobbyn HC, Elia A Kress TR, Dickens M, Clemens MJ, Heery DM, Gaestel M, Eilers M, Willis AE, Bushell M: p38 MAPK/MK2-mediated induction of miR-34c following DNA damage prevents Myc-dependent DNA replication. Proc Natl Acad Sci USA 2010, 107:5375-5380.

18. Wei JS, Song YK, Durinck S, Chen QR, Cheuk AT, Tsang P, Zhang Q, Thiele CJ, Slack A, Shohet J, Khan J: The MYCN oncogene is a direct target of miR-34a. Oncogene 2008, 27:5204-5213.

19. Tan X, Martin SJ, Green DR, Wang JY: Degradation of retinoblastoma protein in tumor necrosis factor- and CD95-induced cell death. J Biol Chem 1997, 272:9613-9616.

20. Karamitopoulou E, Cioccari L, Jakob S, Vallan C, Schaffner T, Zimmermann A, Brunner T: Active caspase 3 and DNA fragmentation as markers for apoptotic cell death in primary and metastatic liver tumours. Pathology 2007, 39:558-564.

21. Karube $Y$, Tanaka $\mathrm{H}$, Osada $\mathrm{H}$, Tomida S, Tatematsu $\mathrm{Y}$, Yanagisawa $\mathrm{K}$, Yatabe Y, Takamizawa J, Miyoshi S, Mitsudomi T, Takahashi T: Reduced expression of Dicer associated with poor prognosis in lung cancer patients. Cancer Sci 2005, 96:111-115.

22. Gao W, Yu Y, Cao H, Shen H, Li X, Pan S, Shu Y: Deregulated expression of miR-21, miR-143 and miR-181a in non small cell lung cancer is related to clinicopathologic characteristics or patient prognosis. Biomed Pharmacother 2010, 64:399-408.

23. Zhang JG, Wang JJ, Zhao F, Liu Q, Jiang K, Yang GH: MicroRNA-21 (miR21) represses tumor suppressor PTEN and promotes growth and invasion in non-small cell lung cancer (NSCLC). Clin Chim Acta 2010 411:846-852.

24. Baek D, Villen J, Shin C, Camargo FD, Gygi SP, Bartel DP: The impact of microRNAs on protein output. Nature 2008, 455:64-71.

25. Linsley PS, Schelter J, Burchard J, Kibukawa M, Martin MM, Bartz SR, Johnson JM, Cummins JM, Raymond CK, Dai H, Chau N, Cleary M, Jackson AL, Carleton M, Lim L: Transcripts targeted by the microRNA-16 family cooperatively regulate cell cycle progression. Mol Cell Biol 2007, 27:2240-2252.

26. Liu Q, Fu H, Sun F, Zhang H, Tie Y, Zhu J, Xing R, Sun Z, Zheng X: miR-16 family induces cell cycle arrest by regulating multiple cell cycle genes. Nucleic Acids Res 2008, 36:5391-5404.

27. Reed MF, Zagorski WA, Knudsen ES: RB activity alters checkpoint response and chemosensitivity in lung cancer lines. J Surg Res 2007, 142:364-372.

28. Evan Gl, Vousden KH: Proliferation, cell cycle and apoptosis in cancer. Nature 2001, 411:342-348.

29. Bueno MJ, Perez de Castro I, Malumbres M: Control of cell proliferation pathways by microRNAs. Cell Cycle 2008, 7:3143-3148.

30. Carleton M, Cleary MA, Linsley PS: MicroRNAs and cell cycle regulation. Cell Cycle 2007, 6:2127-2132.

31. Morgan DO: Cyclin-dependent kinases: engines, clocks, and microprocessors. Annu Rev Cell Dev Biol 1997, 13:261-291.

32. Tazawa H, Tsuchiya N, Izumiya M, Nakagama H: Tumor-suppressive miR34a induces senescence-like growth arrest through modulation of the E2F pathway in human colon cancer cells. Proc Natl Acad Sci USA 2007, 104:15472-15477.

33. Welch C, Chen Y, Stallings RL: MicroRNA-34a functions as a potential tumor suppressor by inducing apoptosis in neuroblastoma cells. Oncogene 2007, 26:5017-5022.

34. Girard L, Zochbauer-Muller S, Virmani AK, Gazdar AF, Minna JD: Genomewide allelotyping of lung cancer identifies new regions of allelic loss, differences between small cell lung cancer and non-small cell lung cancer, and loci clustering. Cancer Res 2000, 60:4894-4906.

35. Lodygin D, Tarasov V, Epanchintsev A, Berking C, Knyazeva T, Korner H, Knyazev P, Diebold J, Hermeking H: Inactivation of miR-34a by aberrant CpG methylation in multiple types of cancer. Cell Cycle 2008, 7:2591-2600.

36. Hermeking H: MiR-34a and p53. Cell Cycle 2009, 8:1308.

37. Lerner M, Harada M, Loven J, Castro J, Davis Z, Oscier D, Henriksson M, Sangfelt O, Grander D, Corcoran MM: DLEU2, frequently deleted in malignancy, functions as a critical host gene of the cell cycle inhibitory microRNAs miR-15a and miR-16-1. Exp Cell Res 2009, 315:2941-2952.

38. Chang TC, Yu D, Lee YS, Wentzel EA, Arking DE, West KM, Dang CV, Thomas-Tikhonenko A, Mendell JT: Widespread microRNA repression by Myc contributes to tumorigenesis. Nat Genet 2008, 40:43-50.

39. Hermeking H: p53 enters the microRNA world. Cancer Cell 2007, 12:414-418.

40. Suzuki HI, Yamagata K, Sugimoto K, Iwamoto T, Kato S, Miyazono K: Modulation of microRNA processing by p53. Nature 2009, 460:529-533.

41. Navarro A, Diaz T, Gallardo E, Vinolas N, Marrades RM, Gel B, Campayo M, Quera A, Bandres E, Garcia-Foncillas J, Ramirez J, Monzo M: Prognostic implications of miR-16 expression levels in resected non-small-cell lung cancer. J Surg Oncol 2011, 103:411-415.

42. Ivanovska I, Cleary MA: Combinatorial microRNAs: working together to make a difference. Cell Cycle 2008, 7:3137-3142.

43. Hayes GD, Frand AR, Ruvkun G: The mir-84 and let-7 paralogous microRNA genes of Caenorhabditis elegans direct the cessation of molting via the conserved nuclear hormone receptors NHR-23 and NHR25. Development 2006, 133:4631-4641.

44. Nachmani D, Lankry D, Wolf DG, Mandelboim O: The human cytomegalovirus microRNA miR-UL112 acts synergistically with a cellular microRNA to escape immune elimination. Nat Immunol 2010, 11:806-813.

45. Heneghan HM, Miller N, Kerin MJ: MiRNAs as biomarkers and therapeutic targets in cancer. Curr Opin Pharmacol 2010, 15:673-682.

46. Zhang $S$, Chen L, Jung EJ, Calin GA: Targeting microRNAs with small molecules: from dream to reality. Clin Pharmacol Ther 2010, 87:754-758.

47. Sarkar FH, Li Y, Wang Z, Kong D, Ali S: Implication of microRNAs in drug resistance for designing novel cancer therapy. Drug Resist Updat 2010, 13:57-66.

48. Seto AG: The road toward microRNA therapeutics. Int I Biochem Cell Biol 2010, 42:1298-1305.

49. Petri A, Lindow M, Kauppinen S: MicroRNA silencing in primates: towards development of novel therapeutics. Cancer Res 2009, 69:393-395.

50. Wiggins JF, Ruffino L, Kelnar K, Omotola M, Patrawala L, Brown D, Bader AG Development of a lung cancer therapeutic based on the tumor suppressor microRNA-34. Cancer Res 2010, 70:5923-5930.

doi:10.1186/1476-4598-10-55

Cite this article as: Bandi and Vassella: miR-34a and miR-15a/16 are coregulated in non-small cell lung cancer and control cell cycle progression in a synergistic and $\mathrm{Rb}$-dependent manner. Molecular Cancer 2011 10:55.

\section{Submit your next manuscript to BioMed Central and take full advantage of:}

- Convenient online submission

- Thorough peer review

- No space constraints or color figure charges

- Immediate publication on acceptance

- Inclusion in PubMed, CAS, Scopus and Google Scholar

- Research which is freely available for redistribution 